\title{
ENTREPRENEURIAL INTENTIONS AND ENTREPRENEURSHIP IN EUROPE COUNTRIES
}

\begin{tabular}{|r|l|}
\hline Journal: & International Journal of Innovation Science \\
\hline Manuscript ID & IJIS-07-2017-0062.R1 \\
\hline Manuscript Type: & Original Research \\
\hline Keywords: & Entrepreneurship, Entrepreneurial Intentions, GEM, Europe \\
\hline Note: The following files were submitted by the author for peer review, but marked to be sent in Off-Line. \\
\hline $\begin{array}{l}\text { Anonymous Article } \\
\text { Tables and figures } \\
\text { Figure 1 }\end{array}$ \\
\hline
\end{tabular}

SCHOLARONE $^{\text {"x }}$

Manuscripts 

IN EUROPE COUNTRIES

\begin{abstract}
The significant importance of entrepreneurship for the economic development, job creation and innovation have increased the concerns of researchers and decision makers at different levels for the understanding and investigation of the factors that could have an impact on the level of entrepreneurial activity. In fact, differences in entrepreneurial activity and entrepreneurship are substantial, persistent and distinct from their background in different nations and / or regions, especially in Europe. Theoretical studies and empirical studies confirm that the entrepreneurial activities of individuals are the main drivers of the development of entrepreneurship, namely in terms of economic growth, mainly through the contribution to the creation of new jobs, the development of competitiveness and innovations at the enterprise.

For this purpose, we used two Global Databases Entrepreneurship Monitor (GEM) of the year 2015 , which were duly adapted and thus created the database for the analysis of this study, having as justification performed literature review considered the variables necessary for this purpose. Results reveal that the key determinants of the entrepreneurial intention in the European countries are: "perceived capacity" by the individual; the "entrepreneurial intention" itself which will, in fact, influence the "rate of nascent entrepreneurship"; the "governmental and political factors" in relation to the respective "financing for the entrepreneur", and the "basic education and training" in entrepreneurship which influence "research \& development".
\end{abstract}

Keywords: Entrepreneurship, Entrepreneurial Intentions, GEM, Europe. 


\section{INTRODUCTION}

The understanding of the level of entrepreneurial intentions has purposes and potential for policy makers and researchers to predict future entrepreneurship activities that can be used to achieve economic goals. In other words, entrepreneurial intent is defined as the intention of an individual has to start their own business and is the main predictor of future entrepreneurs (Yıldırım, Çakır, \& Aşkun, 2016).

In the current world, changes are increasingly constant and uncertain, reflecting in the behaviour and conditions of society. Due to this diversity of contexts and motivations, the entrepreneur and his entrepreneurial intentions arise. With entrepreneurship being a global phenomenon, which stems from profound changes in national and international relations, in the industrial society among the mode of production, the job market and vocational training, being entrepreneurial and putting into practice your intentions is indispensable, with the basis for success not only being personal, business, but from the country where it operates. In general, it can be said that entrepreneurship means securing financial gain; making plans and establishing goals; having business acumen, making things happen, not being afraid; taking and knowing how to deal with risks; being up-dated; following dreams; having a financial reserve and mainly, knowing how to manage. Deep down these characteristics can be related to the theory of Hisrich \& Peter (2004) which highlights what entrepreneurship demands: dedication, effort and above all the entrepreneur being available to take financial, psychological and social risks to obtain what is desired (Marques, Ferreira, Gomes and Rodrigues, 2012). Thus, entrepreneurship is the capacity to create or identify business opportunities and explore them, with a view to create value and profit (Shane \& Venkataraman, 2000).

In relation to entrepreneurial intentions, they are a consolidated area in terms of research within entrepreneurship, despite being a knowledge still quite emerging and requiring further investigation to progress in terms of a better understanding of the intentions of the entrepreneurs (Liñán \& Fayolle, 2014).

In fact, in the last decades, entrepreneurship and entrepreneurial intentions have gained increasing attention from academics, governments and politicians around the world, there being an international consensus on the major role of entrepreneurship for economic development, job creation and innovation (Raposo, Rodrigues, Dinis, Paço and Ferreira, 2014). Also, the economic recession and the significant increase in unemployment, in the context of the recent international crisis, have renewed the researcher' interest on the role of entrepreneurship and its determinant factors.

In this context, our study aims to empirically evaluate and identify the key determinants of the level of entrepreneurial activity for 22 European countries, using two databases from Global Entrepreneurship Monitor (GEM) for the periods 2007-2015 and 2001-2015. In fact, there is still no known study that has encompassed the 22 European countries and with so recent GEM data that goes up to the year 2015. Moreover, the study is very useful to understand the effect of several variables in different European countries and entrepreneurial intentions.

To meet this objective, we have structured our study as follows: section 2 is a literature review; section 3 presents the methodology used; section 4 includes data analyses and results discussions; section 5 there are the conclusions; and the last section 6 have the references. 


\section{LITERATURE REVIEW}

\subsection{Entrepreneurship and driving forces}

One of the concepts still in use today, belongs to the economist Schumpeter, who associates entrepreneurship with innovation. Based on Schumpeter, Fillion (1998) considers the entrepreneur as a motor in the economic system, searching for new opportunities and taking risks. For Drucker (1999) entrepreneurship requires some risk in business and the entrepreneurs are individuals who take advantage of opportunities to produce change. Entrepreneurship received strong contributions from various areas of knowledge, such as psychology and sociology, which led to some variations to its definition (Oliveira, 2010).

To Hisrich \& Peters (1998) entrepreneurship considers business, management and individuals; and despite the various distinct definitions, they are consensual in initiative, organization and reorganization of the social and economic mechanisms, which transform resources into results, in the risk acceptance and / or failure.

Fillion (1999) distinguishes the role of the entrepreneur and the owner, as some people have the role of entrepreneur without having created an enterprise and others are owners of small businesses because they bought them and not because they created them.

Entrepreneurship is the capacity to create or identify business opportunities and explore them aiming at the creation of value and profit (Shane \& Venkataraman, 2000).

To Oliveira (2010) entrepreneurship is an evolutionary and innovative process of the capacity and professional skills directed to the results and the consolidation of new strategically relevant projects.

To the European Commission (2003) entrepreneurship is "a mental attitude that encompasses the motivation and the ability of the individual, to identify an opportunity and realize it with the aim to produce a determined value or economic result." Entrepreneurship is actions derived from innovation (Galvão, Mascarenhas, Rodrigues, Marques and Leal, 2017), creativity or a new vision of something already in existence, whose people or teams possess special characteristics, which question, analyse the problems through another prism, take risks and undertake tasks (Dornelas, 2005).

Per Timmons (1999) entrepreneurship is the distribution of value, with benefits for the individual, organization and society, in which stability and its monetary return are related and associated with personal satisfaction.

To GEM (2013) entrepreneurship is "any attempt to create a new business or new initiative, own job, a new business organization or expansion of an existing business". GEM Portugal (2011) identifies 9 driving forces of entrepreneurship: (1) Financial Support - Availability of financial resources, equity and debt amortization funds, including grants and subsidies; (2) Governmental Policies - Degree to which Governmental policies on taxes, regulations and their application are neutral; (3) Governmental programs - The existence of program, which directly supports new and growing businesses; (4) Education and Training - Training on the creation or management of new and growing businesses is included in education and training; (5) Transfer of Research and development - I\&D on a national level which leads to new commercial opportunities and access by small, new or growing businesses; (6) Commercial and Professional Infrastructure - Influence from institutions and commercial, accounting and legal services; (7) Opening in the Market/Barriers to Entry - Agreements and commercial procedures that are subject to changes and replacements, and prevents new and growing companies from competing; (8) Access to Physical Infrastructures - Access to physical 
resources at a price that is not discriminatory; (9) Cultural and Social Norms - Social and cultural norms which encourage individual initiatives that lead to new forms of conducting business and economic activities. There are various factors, which influence entrepreneurship; psychological, environmental, sociodemographic and training, as well as the social, political, cultural, economic and infrastructural components (Almeida, 2014).

The European Commission enhances entrepreneurship as it has been adopting a strategy through teaching and learning, with basis on an integrated policy, whose objective is to change mentalities, but also improve competencies and remove barriers that hinders the creation, transmission and growth of enterprises (European Communities Commission, 2006).

\subsection{Entrepreneurial Intentions and its driving forces}

Koe, Majid, and Ismail (2012), refer knowledge, business experience and attitude, while Gelderen, Kautonen, and Fink (2015) refer emotions, as a factor for entrepreneurial intention. In relation to genre, Santos, Roomi, and Liñán (2016) claim that males display more favourable entrepreneurial intentions, once women are more likely to fear failure, and men demonstrate greater self-confidence in their ability to start a business (Santos, Silva, Rodrigues, Marques and Leal, 2017). Drnovsek \& Erikson (2005) refer social, political and economic factors for the entrepreneurial intention as well as personality aspects, skills and personal convictions. The study of Bayon, Vaillaint and Lafuente (2015) in their outcomes reveal that perceived entrepreneurial ability has a distinct positive influence and intentions on the decision to initiate entrepreneurial activities and its impact is greater than that of actual abilities. Furthermore, it is verified evidence of a positive interaction effect suggesting that perceived entrepreneurial ability is key to inspiring nascent entrepreneurial initiatives between those with high ability.

Ajzen (1991) addresses three motivational factors that influence behaviour: behavioural control (perception of the facility or difficulty in the realization of behaviour of interest in becoming entrepreneurial); attitude in relation to behaviour (degree in which a positive or negative personal evaluation on the fact of being entrepreneurial is presented): and the perception of the norms of society (which measure the perceived social pressure to perform or not entrepreneurial behaviour).

In summary, the following hypothesis can be formulated:

$\checkmark$ H1: High levels of perceived capacity by the individual positively influence entrepreneurial intentions.

Liñán et al. (2011), investigated the regional variations that may occur and conclude that in more developed regions, the business intention is greater.

The literature states that there is a link between the perception of desirability and the entrepreneur's intention to start a new enterprise (Krueger, 1993; Krueger et al., 2000; Singh et al., 2016).

Therefore, the following hypothesis can be formulated:

$\checkmark$ H2: High levels of perceived opportunities by the individual positively influence entrepreneurial intentions.

Current studies propose that cognition in the form of how individuals perceive their entrepreneurial ability to play a role in the later. For instance, those who develop positive perceptions about their entrepreneurial 
ability are more likely to initiate nascent entrepreneurial activities than others (Arenius \& Minniti, 2005; DeClercq et al., 2011; Koellinger et al., 2007; Lafuente et al., 2007; Townsend et al., 2010).

But, judgments based on perceptions are often inaccurate (Kruger \& Duning, 1999; Moore \& Small, 2007). Inaccurate perceptions have opposite effect on the decision to initiate nascent entrepreneurial activities especially among individuals with differences in abilities. For instance, while favourable perceptions of entrepreneurial ability lead to business entry by individuals with low ability (DeClercq et al., 2011; Hayward et al., 2006), individuals with high ability refrain from entrepreneurship because of unfavourable perceptions of their entrepreneurial ability (Hartog et al., 2010; Kruger \& Dunning, 1999).

In this context, the following research hypothesis is formulated:

$\checkmark$ H3: The entrepreneurial intention positively influences the rate of Nascent Entrepreneurship.

Kibler (2013) says the political and economic factors could limit entrepreneurial intention, such as population density, level of education, wealth and employment rate while Liñán \& Santos (2007) claim socio-economic factors as important in terms of behaviour towards entrepreneurial intention.

Though, this approach has been criticized by many authors (McSweeney, 2002; Soussi \& Côté, 2006) since scores are averages, which may vary significantly from one individual to another. In addition, greatest of these studies have focused on countries rather than entrepreneurs who make financial decisions. Considering the actual cultural beliefs of decision makers is therefore necessary.

The negative association of secrecy with the entrepreneur's intention to use bank-financing raises another problem as the entrepreneur has no incentive to turn to banks. This behaviour may result from the fact that he does not want to disclose information on the company's activities because of the fear that this information may be used by competitors or banks for strategic purposes or by his employees against him (Makpotche, Logossah, Amewokunu, Lawson-body, \& Sedzro, 2015).

From the above discussion, we suggest:

$\checkmark \quad$ H4: Financing for entrepreneurs positively influence entrepreneurial intentions.

According to (Obaji \& Olugu, 2014) the case of government support policies, it is assumed that since government is in the lead for entrepreneurial development, it would provide the much required resources within its capability. Such resources contain provision of environment conducive to business that will highly promote entrepreneurship. The Government policy in this context is any course of action, which aims at regulating and improving the conditions in terms of supportive, implementation and funding policies by the government. Based on this definition, government policy as it relates to entrepreneurial practice is targeted at encouraging entrepreneurship by making a favourable environment for the entrepreneurs.

Literature from several studies have shown that government policy is positively related to entrepreneurship (Mason, C. \& Brown, R., 2011; Greene, F., 2012).

As a result, the following hypothesis is proposed:

$\checkmark$ H5: Governmental support and policies positively influence entrepreneurial intentions.

To Bird (1988) intention refers to the state of spirit of the person (experiments the action), for a specific object (goal) or a path to achieve something (means). The intention to possess a determined behaviour can be affected by various personal characteristics: necessity, values, wishes, habits and beliefs. 
The personal characteristics of the entrepreneur are decisive in terms of influence on the entrepreneurial intention such as values, attitudes, knowledge and skills, wishes and personal factors (Vesalainen \& Pihkala, 2000; Papzan et al., 2013; Lee et al., 2011; Fitzsimmons \& Douglas, 2011; Kautonen et al., 2015).

Demographic and human variables such as age and personal characteristics, values, attitudes and motivation are important and decisive aspects for the training of entrepreneurial intention (Liñán \& Chen, 2009; Liñán \& Fayolle, 2014).

The individual's education/culture also influences the entrepreneurial intention (Liñán et al., 2011). Various studies show cultural values for the entrepreneurial intentions (Rantanen \& Toikko, 2013; Siu \& Lo, 2013). Shneor et al. (2013), identify the educational environment in training of entrepreneurial intention. To reinforce this educational element, Ozgul \& Kunday (2015), create a concept that called "academic entrepreneur", whose entrepreneur is the university student who investigates and later creates his /her enterprise. To (Paço, Ferreira, Raposo, Rodrigues and Dinis, 2011), education and training are important as they can change an individual's personal attitudes in relation to competencies, skills and cultural conscience. Education and training for entrepreneurship have been the most used means to leverage business activity (Levie \& Autio, 2008; Saraiva \& Gabriel, 2016). Education and training activities specifically tailored for entrepreneurship are usually aimed at increasing the supply through different mechanisms, which normally involve the transmission of necessary instrumental skills to start and grow a new company (Honig, 2004).

This discussion lends support to the following hypothesis:

$\checkmark$ H6: Basic education and training in entrepreneurship positively influence entrepreneurial intentions.

Dutta et al. (2015) in their research conclude that innovation and technology are a critical engine for entrepreneurial intentions, that is, they affirm that there is in fact an awareness and perception on the part of the entrepreneur that technological innovation is very important for the promotion of any entrepreneurship activity. Thus, these authors verify that the capacity for personal innovation in technology, knowledge and experience of the entrepreneur act as key factors for the development of entrepreneurial intention.

These arguments generate the following hypothesis:

$\checkmark \quad$ H7: The level of research and development $(R \& D)$ positively influence entrepreneurial intentions.

The influence of the national culture of a country is a fundamental condition that influences any business intention (Mueller et al., 2014). For Liñán, Nabi, and Krueger (2013) to incorporate the role of culture with the motivations, skills and entrepreneurial knowledge is very important. According, Mitchell et al. (2002) to start a new business many factors influence the entrepreneur's intention as desirability, viability and entrepreneurial experience, but the culture varies from country to country, that is, the studies are still not clear about the impacts of the culture in the intention of the entrepreneur. Therefore, each country has its own culture, values, norms and beliefs that affect entrepreneurial intention.

For the formation of entrepreneurial intentions, the influence of the perception of norms (Ajzen, 1991) is verified, that is, it is the perceived beliefs of an individual that act on their expected behaviour, which can strengthen or diminish their entrepreneurial intentions (Schlaegel \& Koenig, 2014; Forster \& Grichnik, 2013).

Thus, in view of the above observations, the following hypothesis is suggested:

$\checkmark \quad$ H8: Culture and social norms held by the individual positively influences entrepreneurial intentions. 
European governments view entrepreneurship as a key factor in creating economic growth and new jobs so that economic policies stimulate and influence entrepreneurial intentions (Castaño et al., 2016). Saraiva \& Gabriel (2016) conclude in their studies that, in the context of the European context characterized by economic stagnation and structural unemployment, the European authorities play a key role, in close cooperation with the Member States, in the development of policies and Public programs that promote the development of certain activities and training in collaboration with schools and the various training entities in order to bring young people closer to entrepreneurship as a means of preparing them for new business challenges. Paul et al (2017) refer culture and an individual's proactive personality directly determine the degree of entrepreneurial intention

In light of the above, the following hypothesis is suggested:

$\checkmark$ H9: Governmental support and policies positively influence the rate of nascent entrepreneurship.

According Miranda et al. (2017), the intervention of the public authorities is crucial and most important to improve the attitude of an individual to the development of his entrepreneurial intention in his academic learning, and therefore, it would be interesting to increase systems So that they not only look at their performance in terms of research, but also the transfer of research results to production (patent licensing, collaborative projects, spin-off creation, etc.).

In fact, the literature has investigated this issue of government policies and their impact on entrepreneurship regulation (Campbell \& Mitchell, 2012). Kreft \& Sobel (2005) argue that an environment with low taxes, low regulations and private property rights are needed to encourage entrepreneurial activity.

In accordance with the above, the following research hypothesis is announced:

$\checkmark$ H10: Governmental factors and policies positively influence high levels of funding for the entrepreneur.

To Fini et al., (2012) the entrepreneurial intention is a cognitive representation of actions to be implemented by the individual, which identify individual characteristics and business knowledge for the entrepreneurial intention. Several studies have found empirical evidence in which education in entrepreneurship is considered to be very important for the development of entrepreneurship intentions (Entrialgo \& Iglesias, 2016; Paço, Ferreira, Raposo, Rodrigues, Dinis, 2015; Rodrigues, Dinis, Paço, Ferreira and Raposo, 2012; Sánchez, 2013; Saraiva \& Gabriel, 2016) and many transformations are happening in schools around the world regarding entrepreneurship education. Conceptual and technological changes due to the revolution in the global, social, political and technological environment (Welsh et al., 2016).

Building on this, the following research hypothesis is proposed:

$\checkmark$ H11: Basic education and training in entrepreneurship positively influence the level of investigation and development.

\section{METHODOLOGY}

To analyse entrepreneurial intentions in Europe, two databases from Global Entrepreneurship Monitor (GEM) were used: "GEM NES Key Indicators 2007-2015" and "GEM APS Key Indicators 2001-2015", available at http://www.gemconsortium.org/data/sets, considering data from 2015.

From the original database containing 60 countries, European countries were selected, resulting in a 22 countries list: Portugal, Spain, Greece, Italy, Belgium, Germany, Ireland, Luxembourg, the Netherlands, 
Switzerland, the United Kingdom, Croatia, Hungary, Poland, Romania, Slovakia, Slovenia, Estonia, Finland, Latvia, Norway and Sweden.

Table 1 identifies the dependent and independent variables of our study.

[Insert table 1 about here]

Regarding the variables in analysis, the first database includes twenty variables and the second eleven variables. Justified by the literature review, 16 and 17 variables respectively, were excluded, as they did not fit the required analysis. The adapted database contains nine variables (see table 2), the dependent variables are EI, NE, FE, R\&D and the independent variables are PC, PO, EI, FI, GS, BET, R\&D, CSN.

According to GEM 2015, we have: Variables EI, PC, PO and NE: Individuals aged 18-64 (in percentage) that believe they have skills and knowledge to start a business; Variable FI: Availability of financial equity and debt resources, including grants and subsidies; Variable GS: Public policies that support entrepreneurship; Variable BET: Training, considering primary and secondary; Variable R\&D: Research and development which will lead to new commercial opportunities; and Variable CSN: Social and cultural norms which encourage or allow actions that lead to new business methods or activities which can increase personal wealth and income.

Also, according to GEM, the variables EI, PC, PO and NE refer to the attitudes, activities and aspirations of the population in relation to entrepreneurship. The other variables FI, GS, BET, R\&D and CSN refer to the evaluations on the environment to start new businesses.

Table 2 contains the adapted GEM database used in this study, which contains the 22 European Union countries and the 9 variables in study.

[Insert table 2 about here]

\section{DATA ANALYSES AND RESULTS DISCUSSION}

Table 2 shows the countries with greater incidence in relation to the variables: Romania has the highest "Entrepreneurial Intention", Poland "Perceived Capabilities", Switzerland "Perceived Opportunities", Estonia” Nascent Entrepreneurship Rate", Holland "Financing for entrepreneurs Governmental support and policies", Portugal "Basic-school Entrepreneurial Education and training" and Sweden "R\&D Transfer" and "Cultural and social norms". 
[Insert table 3 about here]

In table 3, descriptive statistics and the study of normality of the variables under review are identified by the test of Kolmogorov-Smirnov.

From this table 3, we can conclude that all the variables are approximated to normal distribution $(\mathrm{p}>0.05)$, followed by the option of parametric procedures. According to table 3, it is possible to describe the study variables, as follows. In Figure 1 below, it is possible to analyse Mean Distribution "Entrepreneurial Intention" by countries.

[Insert figure 1 about here]

In relation to variables, it is possible do describe individually the following: "Entrepreneurial Intention" (EI), a sharp and high dispersion of results with a coefficient of variations of almost $50 \%(6,02 / 12,62=0,477)$, appears, showing a high variability of results from this sample, being verified values between 4,78 and 29 , 01. In fact, with a mean of IE of 12.62 for all European countries, the countries with the highest IE are Romania and Less EI are Norway, as can be seen in figure 1, and table 2 and table 3.

"Perceived Capabilities" (PC), has a reduced dispersion coefficient since it has a smaller dispersion of values, also. It can be observed, in general, that a percentage of respondents with the ability to start a business are situated below $50 \%,(6.85 / 42.91=0.160)$ with few cases above this value. In fact, with a (Mean of $\mathrm{PC}=42,91$ ) for all European countries, being verified values between 30,5 and 55,92 , in which the largest country is Poland and the smallest is Italy.

"Perceived Opportunities" (PO), confirms a sharp variation (between 14.19 e 70.22), where most values, that is, in most countries less than $40 \%$ of the respondents perceive good business opportunities and there are only 3 countries where the percentage exceeds $50 \%$, respondents with the ability $(14.47 / 37.56=0.385)$, and with a (Mean PO $=37.56)$. The extreme value of this variable corresponds to Germany with approximate values than 38.27 , and Ireland to 39.35 .

"Nascent Entrepreneurship Rate" (NE), presents reduced values, that is, less than $10 \%$ of the population of each country believes to have the abilities and knowledge necessary to start a business, and equally having a larger concentration in the lower values, respondents with the ability $(1.80 / 4.97=0.362)$, and with a (Mean NER $=4.97)$. The extreme value of this variable corresponds to Switzerland with approximate values than 4.79, and Croatia to 5.11 .

"Financing for Entrepreneurs" (FE), shows that the largest number of answers (six respondents) are found at point 4, with a distribution approximate to the normal curve and the absence of outliers; respondents with the ability $(71 / 4.43=16.027)$, and with a $($ Mean FE $=4.43)$. The extreme value of this variable corresponds to Latvia with approximate values than 4.50 . 
"Governmental support and policies" (GS), shows that the highest number of answers (six respondents) are found at point 3.5, with a distribution approximate to the normal curve and absence of outliers; respondents with the ability $(1 / 4.25=0.235)$, and with a (Mean GSP $=4.25)$. The extreme value of this variable corresponds to Germany.

"Basic-school Entrepreneurial Education and training" (BET), indicates that the highest number of answers (eight respondents) are found at point 3.5, with a distribution approximate to the normal curve and absence of outliers, respondents with the ability $(0.91 / 3.55=0.256)$, and with a $($ Mean BET $=3.55)$. The extreme value of this variable corresponds to Spain and Luxembourg with approximate values than 3.50 both countries.

"R\&D Transfer" (R\&D), points out that the highest number of answers (nine respondents) are found at point 3.5 , with a distribution approximate to the normal curve and the existence of an outlier can be verified, which allows the distortion of the mean and standard deviation; respondents with the ability $(0.78 / 4.18=0.187)$, and with a (Mean $R \& D=4.18$ ). The extreme value of this variable corresponds to United Kingdom.

"Cultural and social norms" (CSN), indicates that the highest number of answers (seven respondents) are found at point 4 , with a distribution approximate to the normal curve and absence of outliers, respondents with the ability $(0.89 / 4.42=0.201)$, and with a (Mean CSN $=4.42$ ). The extreme value of this variable corresponds to Spain and Finland with approximate values.

To validate the hypotheses, Pearson's correlations were performed which show an association between variables, whose results can be observed in table 4 .

[Insert table 4 about here]

Through the analysis of table 4, it is observed that the correlation between "CP" with "EI" ( $\mathrm{r}=0.543, \mathrm{p}$ $<0.01)$ and "NE" with "EI" $(r=0.745, \mathrm{p}<0.01)$ have statistical significance, that is the correlation that is established between them is positive and significant, so it is concluded that $\mathrm{H} 1$ and $\mathrm{H} 3$ are validated. There are negative correlations between the variables "PO" with "EI", "FE" with "EI", "GS" with "EI", "BET" with "EI", "PO" with "EI", "R \& D" "With" EI ", and finally between" CSN "with" EI ", thus concluding that there is a negative association between these variables and therefore $\mathrm{H} 2, \mathrm{H} 4, \mathrm{H} 5, \mathrm{H} 6, \mathrm{H} 7$ and $\mathrm{H} 8$ are not validated. In relation to the correlation between "GS" and "NE" there is a positive but very weak correlation, almost non-existent, so H9 is not validated because the correlation is practically null. In relation to the correlation between "GS" with "FE" $(\mathrm{r}=0.727, \mathrm{p}<0.01)$ and between "R \& D" and "BET" $(r=0.702, p<0.01)$, a strong and significant correlation, $\mathrm{H} 10$ and $\mathrm{H} 11$ being validated and confirmed respectively. It should be noted that there is a very significant positive correlation between variables whose hypotheses have not even been raised since they are not included in literature and studies. To deepen the analysis, it was decided to predict the variable "EI" through other indicators, performing a multiple linear regression. In the multiple linear regression, the existence of a linear relationship between variable $\mathrm{Y}$ (the dependent variable) and $\mathrm{k}$ (independent variables) is assumed. The independent variables are used to explain the variation of $\mathrm{Y}$ or even to predict it. 
Thus, it intends to understand until what point some variables ("NE", "PC", "PO", "FI", "GS", "BET", "R\&D" and "CSN") are explanatory or predictive for "EI" to achieve a regression model that allows performing the estimation of values in countries with similar characteristics with the sample, based on known parameters. Therefore, we intend to understand which variables contribute significantly to explain "EI" with a multiple linear regression model with stepwise method. The linear regression analysis was performed to estimate the regression coefficients, and the following 4 outputs were obtained in this analysis (tables 5.1, $5.2,5.3$ and 5.4).

\section{[Insert table 5.1 about here]}

[Insert table 5.2 about here]

[Insert table 5.3 about here]

Thus, to explain Entrepreneurial Intention, 8 dependent variables were introduced and through the Stepwise method, after 2 iterations, following significant models $(F=18.755, p<0,001)$ was obtained with the inclusion of 2 variables (table 5.3.). Thus, the most important variables are "Nascent Entrepreneurship Rate" and "R\&D Transfer" as they present less weight in the equation (through the analysis of standardized coefficients).

[Insert table 5.4 about here] 
The assumptions of the model were analysed, namely the normal distribution, homogeneity and independence of errors. The first two assumptions were validated graphically and the independence assumption was validated using the Durbin-Watson statistic $(d=1.741)$, as can be seen in the table 5.2.

VIF was used to diagnose multicollinearity, being verified through the Tolerance values (which should be superior to 0,1 ) and the VIF (Variance Inflation Factor, which should be inferior to 5 or at 10). Here, the Tolerance value is 0,999 and the VIF is 1,001 , clear indicators of the absence of multicollinearity.

The multiple linear regression allowed to identify the variables Nascent Entrepreneurship Rate, $(\beta=0.758), \mathrm{t}$ $(4)=5.692 ; \mathrm{p}<0,001$, e $\operatorname{R} \& D(\beta=-0.330) ; \mathrm{t}(9)=2.476 ; \mathrm{p}<0,001$, as significant predictors of EI. Thus, the most important variables are "NE" and "R\&D" (through the analysis of standardized coefficients).

The exact test for the distribution of the waste can be done with the Kolmogorov-Smirnov test (table 6), resulted in a level of significance below the null hypotheses acceptance threshold, of which it was not concluded that the residues have a normal distribution.

[Insert table 6 about here]

Concluding, it is undesrstood that model is significant, robust and explains $62,8 \%$ of the variance in values of "EI" (value or of $r^{2}=0,664$ and of $r^{2}$ adjusted $=0,628$ ), as can be seen in the table 5.2., also securing several indicators favourable for validating most assumptions.

According to the performed analysis, table 7 presents the conclusions for the formulated hypotheses.

[Insert table 7 about here]

The results of the performed analysis are found in table 7, where out of the 11 formulated hypotheses, only 4 were not rejected, and 8 being rejected. Having as the analysis the adapted GEM database (table 2) and these hypotheses results, this study reveals that the key determinants of the entrepreneurial intention in the European countries are: "perceived capacity" by the individual; the "entrepreneurial intention" itself which will, in fact, influence the "rate of nascent entrepreneurship"; the "governmental and political factors" in relation to the respective "financing for the entrepreneur", and the "basic education and training" in entrepreneurship which influences "research \& development".

So, we can conclude that high levels of capacity perceived by the individual, policies governmental and basic education and training are the most important factors affecting the entrepreneurial intentions of the 22 European Union countries studied.

The empirical results of this research show that a part of the considered indicators is significantly affecting the entrepreneurial activity in the European Union countries, according to the results of other empirical studies, 
evidenced in the literature review carried out.

\section{CONCLUSIONS}

According to the GEM model, business creation occurs when individuals believe they possess the skills, knowledge and motivation to start a business, based on the perception of an opportunity. If we consider the European context characterized by economic stagnation and structural unemployment, the results obtained with this study allow us to perceive the necessity and importance of the aspects of "perceived capacity" and "basic education and training", but also the fact that the European authorities, in close cooperation with the member states, devise public policies, that is "governmental and political factors", as a means of preparing individuals for new business challenges.

About the countries which make up the European Union Poland has greater perceived capacities, Romania has the greatest entrepreneurial intention, Holland has the greatest governmental and political factors regarding financing and Portugal is the country with the highest index in basic education and training in entrepreneurship. The remaining variables are not closely linked to entrepreneurial intentions in Europe related to this group of countries for the year 2015, and not being significantly relevant in entrepreneurial intentions.

The results of our study may be of interest to policy makers so that they perceive and foster entrepreneurship, both at European and national level, in the context of the Europe 2020 Strategy, to adopt appropriate measures to promote and support entrepreneurship. Europe 2020 is the European Union's growth strategy for the next decade. Thus, in a changing world, the EU is to become a smart, sustainable and inclusive economy. These three mutually reinforcing priorities should help Europe achieve high levels of employment, productivity and social cohesion. The European Union has therefore set targets for employment, innovation, education, social inclusion and climate / energy to be achieved by 2020. In this way, policy makers in each country have a key role to play in promoting new entrepreneurship initiatives, for example through legislation that attracts investors, investment support policies, tax benefits, the creation of incubators, subsidies to new graduates, among others.

We note that our study has some limitations, for example, to the extent that the European analysis is a more generalized analysis of the factors as some specificities have been addressed and that should be investigated in other studies. For future research on the explanation of business activity, we must address the methodological problem of distinguishing the effect of entrepreneurial intentions from other determinants, since these also influence entrepreneurial attitudes. Within the regression analysis shown, this problem is circumvented but not yet fully solved, for it is not yet clear to what extent the effect of entrepreneurial intentions on entrepreneurial activity captures the effects of other regional or institutional variables. In addition, more and better indicators need to be included for the demographic, economic and institutional determinants of entrepreneurial intentions and entrepreneurship at the regional level. Despite the conceptual and empirical limitations of our study, our conclusions provide several recommendations for entrepreneurship policy.

\section{REFERENCES}


Ajzen, I. (1991). “The theory of planned behavior”, Organ Behav Hum Decis Process 50 (2). pp. 179-211.

Almeida PIL, Ahmetoglu G, Chamorro-Premuzic T. (2014). Who wants to be an entrepreneur? The relationship between vocational interest and individual differences in entrepreneurship. Journal of Career Assessment 22(1). pp. 102-112.

Almeida, E.S., Haddad, E.A. and Hewings, G.J.D., (2010). The transport-regional equity issue revisited. Regional studies, 44 (10), pp. 1387-1400.

Arenius, P. \& Minniti, M. (2005). "Perceptual variables and nascent entrepreneurship", Small Business Economic, Vol. 24 No. 3, pp. 233-247.

Baron, R. A. (2004). “The cognitive perspective: a valuable tool for answering entrepreneurship's basic "why" questions". Journal of Business Venturing, v. 19, n. 2, pp. 221-239.

Bayon, M. C., Vaillant, Y., \& Lafuente, E. (2015). Initiating nascent entrepreneurial activities: The relative role of perceived and actual entrepreneurial ability. International Journal of Entrepreneurial Behaviour \& Research, 21(1), pp. 27-49.

Bird, B. (1988). "Implementing Entrepreneurial Ideas: The Case for Intention". Academy of Management Review, Vol.13, No.3, pp. 442-453.

Campbell, N., \& Mitchell, D. T. (2012). "A (partial) review of entrepreneurship literature across disciplines". Journal of Entrepreneurship and Public Policy, 1(2), pp. 183-199.

Castaño, M.; Méndez, M. \& Galindo, M. (2016). “The effect of public policies on entrepreneurial activity and economic growth". Journal of Business Research 69 (2016), pp. 5280-5285.

DeClercq, D., Lim, D. S. K. \& Oh, C. H. (2011), "Individual-Level resources and new business activity: The contingent role of institutional context", Entrepreneurship Theory and Practice, V. 37 No. 2, pp. 303330 .

Dornelas, J. C. A. (2005). “Empreendedorismo: Transformando ideias em negócios”. 2a ed. Elsevier.

Drnovsek, M. \& Erikson, T. (2005). "Competing Models of Entrepreneurial Intentions, Economic and Business Review for Central and South-Eastern Europe”, ABI/INFORM

Drucker, P. F. (1999). "Entrepreneurship as a subject of higher education". Seminário: A Universidade Formando Empreendedores. Brasília.

Dutta, K.; Gwebu, L. \& Wang, J. (2015). "Personal innovativeness in technology, related knowledge and experience, and entrepreneurial intentions in emerging technology industries: a process of causation or effectuation?” Int Entrep Manag J, n ${ }^{\circ} 11$, pp. 529-555.

Entrialgo, M. \& Iglesias, V. (2016). "The moderating role of entrepreneurship education on the antecedents of entrepreneurial intention". Int Entrep Manag J 12, pp. 1209-1232.

European Commission (2003). "Green Paper: Entrepreneurship in Europe", Commission of the European Communities.

Filion, L. J. (1998). "Do Empreendedorismo à Empreendedologia. Montreal”. Journal of Enterprising Culture, V6. Tradução e adaptação Jovino Moreira da Silva, M. S. Vitória da Conquista.

Filion, L. J. (1999). "Empreendedorismo: empreendedores e proprietários-gerentes de pequenos negócios". Revista de Administração. São Paulo, V34, 2, pp. 05-28.

Fini, R.; Grimaldi, R.; Marzocchi, G. L. \& Sobrero, M. (2012). "The Determinants of Corporate Entrepreneurial Intention within Small and Newly Established Firms". ET\&P -Entrepreneurship Theory and Practice".

Fitzsimmons, R. J. \& Douglas, E. J. (2011). "Interaction between feasibility and desirability in the formation of entrepreneurial intentions", Journal of Business Venturing 26, pp. 431-440

Forster, F. \& Grichnik, D. (2013). "Why social entrepreneurs act-the intention formation of corporate volunteers". Journal of Social Entrepreneurship, 4(2), pp. 153-181.

Galvão, A. R., Mascarenhas, C., Rodrigues, R. G., Marques, C. S., \& Leal, C. T. (2017). A quadruple helix model of entrepreneurship, innovation and stages of economic development. Review of International Business and Strategy, 27(2).

Gelderen, M. V. \& Kautonen, T. and Fink, M. (2015). "From entrepreneurial intentions to actions: Selfcontrol and action-related doubt, fear, and aversion", Journal of Business Venturing 30, pp. 655-673

GEM (2013). "Global entrepreneurship monitor 2013 global report fifteen years of assessing entrepreneurship across the globe".

GEM (2015). "GEM 2007 - 2015 NES Global Key Indicators”. http://www.gemconsortium.org/data/sets.

GEM Portugal (2011). "Study on Entrepreneurship".

Greene, F., (2012). "Should the focus of publicly provided small business assistance be on start-ups or growth businesses? Ministry of Economic Development, New Zealand.

Hartog, J, Van Praag, M., \& Van Der Sluis, J. (2010), "If you are so smart, why aren't you an entrepreneur? Returns to cognitive and social ability: Entrepreneurs versus Employees", Journal of Economics and Management Strategy, Vol. 19 No. 4, pp. 947-989. 
Hayward, M. L., Dean A. S. \& Griffin, D. (2006), "A hubris theory of entrepreneurship", Management Science, Vol. 52 No. 2, pp. 160-172.

Hisrich, R. D. \& Peters, M. P. (1998). "Entrepreneurship". Irwin/McGraw Hill.

Hisrich, R. D. \& Peters, M. P. (2004). "Empreendedorismo". 5a ed. São Paulo: Brookman.

Honig, B. (2004). "Entrepreneurship education: Toward a modelof contingency-based business planning". Academy of Management Learning and Education, V.3, n³, pp. 258-273.

IBM Corp. Released 2013. IBM SPSS Statistics for Windows, Version 22.0. Armonk, NY: IBM Corp.

Kautonen, T.; Gelderen, M. \& Fink, M. (2015). "Robustness of the Theory of Planned Behavior in Predicting Entrepreneurial Intentions and Actions, ET\&P-Entrepreneurship Theory and Practice".

Kibler, E. (2013). "Formation of entrepreneurial intentions in a regional context, Entrepreneurship \& Reginonal Development", Vol 25, Nos. 3-4, pp. 293-323.

Koe, W-L.; Sa'ari, J. R. \& Majid, I. A. and Ismail, K. (2012). "Determinants of Entrepreneurial Intention among Millennial Generation, Procedia - Social and Beharioral Sciences 40, pp. 197-208.

Koellinger, P., Minniti, M. \& Schade, C. (2007), "I think I can, I think I can: Overconfidence and entrepreneurial behaviour", Journal of Economic Psychology, Vol 28, pp. 502-527.

Kreft, S. F., \& Sobel, R. S. (2005). "Public policy, entrepreneurship, and economic freedom". Cato Journal, 25(3), pp. 595-616.

Krueger, N. (1993). The impact of prior entrepreneurial exposure on perceptions of new venture feasibility and desirability. Entrepreneurship Theory and Practice, 3, pp. 5-21.

Krueger, N., Reilly, M. \& Carsrud, A. (2000). Competing models of entrepreneurial intentions. Journal of Business Venturing, 15(2), pp. 411-432.

Kruger, J. \& Dunning, D. (1999), "Unskilled and unaware of it: How difficulties in recognizing one's own incompetence lead to inflated self-assessments", Journal of Personality and Social Psychology, Vol. 77, pp. 1121-1134.

Lafuente, E., Vaillant, Y. \& Rialp, J. (2007), "Regional differences in the influence of role models: Comparing the entrepreneurial process of Rural Catalonia”, Regional Studies, Vol. 41 No. 6, pp. 779795.

Lee, L.; Wong, K. P. \& Foo, D. M. (2011). "Entrepreneurial Intentions: The influence of organizational and individual fators", Journal of Business Venturing 26, pp. 124-136.

Levie, J. \& Autio, E. (2008). "A theoretical grounding and test of the GEM model". Small Bus Econ, 31, pp. $235-263$

Liñán, F. \& Chen, Yi-Wen (2009). "Development and Cross-Cultural Application of a Specific Instrument to Measure Entrepreneurial Intentions", ET\&P - Entrepreneurship Theory and Practice.

Liñán, F. \& Fayolle, A. (2014). "The future of research on entrepreneurial intentions", Journal of Business Research 67, pp. 663-666

Liñán, F. \& Santos, F. J. (2007). "Does Social Capital Affect Entrepreneurial Intentions?” Int Adv Econ Res pp. 443-453

Liñán, F., Fayolle, A. \& Moriano, J. A. (2014). "Beyond entrepreneurial intentions: values and motivations in entrepreneurship", Int Entrep Manag J 10, pp. 679-689.

Liñán, F., Nabi, C. \& Krueger, N. (2013). "La Intención Empreendedora en Reino Unido Y España: Un Estudio Comparativo", Revista de Economia Mundial 33, pp. 73-103

Liñán, F., Rodriguez-Cohard, J. C. \& Rueda, J. M. (2011). "Factors affecting entrepreneurial intention levels: a role for education", Int Entrep Manag J 7, pp. 195-218

Liñán, F., Urbano, D. \& Guerrero, M. (2011). "Regional variations in entrepreneurial cognitions: Star-up intentions of university students in Spain", Entrepreneurship \& Reginonal Development, Vol. 23, Nos. 3-4, pp. 187-215

Makpotche, M., Logossah, K., Amewokunu, Y., Lawson-body, A., \& Sedzro, K. (2015). Impact of Cultural Beliefs on Entrepreneurs' Intention to use Bank Loans. Journal of Applied Finance \& Banking, 5(4), pp. 11-32.

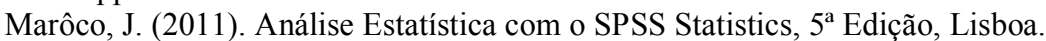

Marques, C. S., Ferreira, J., Gomes, D. N., \& Rodrigues, R. G. (2012). Entrepreneurship education: How psychological, demographic and behavioural factors predict the entrepreneurial intention. Education + Training, 54(8), pp. 657-672.

Mason, C. \& Brown, R., (2011). "Creating good public policy to support high-growth firms". Small Business Economics, 40(2): pp. 211-225.

McSweeney, B. (2002). "Hofstede's model of national cultural differences and their consequences: A triumph of faith-a failure of analysis". Human relations, 55(1), pp. 89-118.

Miranda, F. J., Chamorro-Mera, A. \& Rubio, S. (2017). "Academic entrepreneurship in Spanish universities: An analysis of the determinants of entrepreneurial intention". European Research on Management and Business Economics, V. 23, Issue 2, pp. 113-122. 
Mitchell, R., Smith, J. B., Morsem, E. A., Seawright, K., Peredo, A. M. \& McKenzie, B. (2002). "Are entrepreneurial cognitions universal? Assessing entrepreneurial cognitions across cultures". Entrepreneurship Theory and Practice, 26(4), pp. 9-32.

Moore, D. A. and Small, D. (2007), "Error and bias in comparative judgment: On being both better and worse than we think we are", Journal of Personality and Social Psychology, Vol. 92 No. 6, pp. $972-$ 989.

Mueller, J., Zapkau, F. B. \& Schwens, C. (2014). "Impacto of Prior Entrepreneurial Exposure on Entrepreneurial Intention-Croos-Cultural Evidence", Journal of Enterprising Culture, V.22, 3, pp. 251-282.

Obaji, N. O., \& Olugu, M. U. (2014). "The Role of Government Policy in Entrepreneurship Development”. Science Journal of Business and Management, 2(4), pp. 109.

Oliveira, M. (2010), “Gestão e pedagogia empreendedoras urgem Educador- Empreendedor”. ECCOM, v.1, n.2, pp. 55-60.

Ozgul, U. \& Kunday, O. (2015). “Conceptual Development of Academic Entrepreneurial Intentions Scale”. Procedia - Social and Behavioral Sciences 195, pp. 881-887.

Paul, Justin, Hermel Philippe \& Srivatava, Archana (2017). "Entrepreneurial intentions - theory and evidence from Asia, America, and Europe". Journal of International Entrepreneurship, 15, pp. 324-351.

Paço, A. M. F., Ferreira, J. M., Rodrigues, R. G. \& Dinis, A. (2011). "Behaviours and entrepreneurial intention: Empirical findings about secondary students". Journal of International Entrepreneurship, 9(1), pp. 20-38.

Paço, A., Ferreira, J. M., Raposo, M., Rodrigues, R. G., \& Dinis, A. (2015). Entrepreneurial intentions: is education enough? International Entrepreneurship and Management Journal, 11(1), pp. 57-75.

Papzan, A., Afsharzade, N. \& Moradi, K. (2013). "Entrepreneurial Intention Determinants: An Empirical Model and a Case of Iranian Students in Malaysia", Journal of Entrepreneurship Management and Innovation (JEMI), Volume 9, (3), pp. 43-55.

Rantanen, T. \& Toikko, T. (2013). "Social Values, societal entrepreneurship attitudes and entrepreneurial intention of young people in the Finnish welfare state". Poznan University Economics Review, 1, V.13

Raposo, M., Rodrigues, R. G., Dinis, A., Do Paço, A., \& Ferreira, J. J. (2014). The Influence of Competitiveness and Regulations on Entrepreneurial Activity in Emerging and Advanced Economies. Innovar, 24(1Spe), pp. 113-128.

Rodrigues, R. G., Dinis, A., Paço, A., Ferreira, J., \& Raposo, M. (2012). The effect of an entrepreneurial training programme on entrepreneurial traits and intention of secondary students. In T. BurgerHelmchen (Ed.), Entrepreneurship - Born, Made and Educated, pp. 77-92.

Sánchez, J. C. (2013). "The Impact of an Entrepreneurship Education”. Journal of Small Business Management 2013 51(3), pp. 447-465.

Santos, F. J., Roomi, M. A. \& Liñán, F. (2016). “About Gender Differences and the Social Environment in the Development of Entrepreneurial Intentions”, Journal of Small Business Management 54, pp. 4966.

Santos, G., Silva, R., Rodrigues, R. G., Marques, C., \& Leal, C. (2017). Nascent Entrepreneurs' Motivations in European Economies: A Gender Approach Using GEM Data. Journal of Global Marketing, 30(3), pp. 122-137.

Saraiva, H. I. B. \& Gabriel, V. M. S. (2016). "Entrepreneurship and education in the europe union - student's perception on the subject". The International Journal of Management Science and Information Technology (IJMSIT), (22) pp. $40-58$.

Schlaegel, C. \& Koenig, M. (2014). "Determinants of entrepreneurial intent: A meta-analytic test and integration of competing models". Entrepreneurship Theory and Practice, 38(2), pp. 291-332.

Shane, S. \& Venkataraman, S. (2000). "The promise of entrepreneurship as a field of research". Academy of management review, v.25, n.1, pp. 217-226.

Shneor, R., Camgõz, S. M. \& Karapinar, P. B. (2013). "The interaction betwen culture and sex in the formation of entrepreneurial intentions". Entrepreneurship \& Regional Development, V25, N9-10, pp. 781-803.

Singh, B.; Verma, P. \& KRao, M. (2016). "Influence of Individual and Socio-cultural Factors on Entrepreneurial Intention". South Asian Journal of Management, V. 23, nº 1.

Siu, Wai-sum \& Lo, Eric Siu-chung (2013). "Cultural Contingency in the Cognitive Model of Entrepreneurial Intention”. ET\&P - Entrepreneurship Theory and Practice.

Soussi, S. A., \& Côté, A. (2006). "La diversité culturelle dans les organisations: Analyse critique des fondements théorique du management intercultural”. ASAC 2006, Banff, Alberta.

Strayer, J. F. (2012). "How learning in an inverted classroom influences cooperation, innovation and task orientation”. Learning Environments Research, 15(2), pp. 171-193. 
Timmons, J. (1999). “New Venture Creation: Entrepreneurship for the 21stCentury". 5a ed. Babson Park, Massachusset, Irwin McGraw-Hill.

Townsend, D. M., Busenitz, L. W. \& Arthurs, J. D. (2010), "To start or not to start: Outcome and ability expectations in the decisions to start a new venture", Journal of Business Venturing, Vol. 25 No. 2, pp. pp. 192-202.

Vesalainen, J. \& Pihkala, T. (2000). "Entrepreneurial identity, intentions and the effect of the push factor", International Journal of Entrepreneurship, V4.

Welsh, D. H. B., Tullar, W.L. \& Nemati, H. (2016). "Entrepreneurship education: Process, method, or both?". Journal of Innovation \& Knowledge 1 (2 0 lll 16$)$ pp. 125-132.

Yıldırım, N., Çakır, Ö. \& Aşkun, O. B. (2016). Ready to Dare? A Case Study on the Entrepreneurial Intentions of Business and Engineering Students in Turkey. Procedia -Social and Behavioral Sciences, 229, pp. 277-288. 
Table 2 - Adapted database from the GEM (2015)

\begin{tabular}{|c|c|c|c|c|c|c|c|c|c|}
\hline & $\begin{array}{l}\text { Entrepreneurial } \\
\text { Intention }\end{array}$ & $\begin{array}{c}\text { Perceived } \\
\text { Capabilities }\end{array}$ & $\begin{array}{c}\text { Perceived } \\
\text { Opportunities }\end{array}$ & $\begin{array}{c}\text { Nascent } \\
\text { Entrepreneurship } \\
\text { Rate }\end{array}$ & $\begin{array}{l}\text { Financing for } \\
\text { entrepreneurs }\end{array}$ & $\begin{array}{c}\text { Governmental } \\
\text { support and } \\
\text { policies }\end{array}$ & $\begin{array}{c}\text { Basic-school } \\
\text { Entrepreneurial } \\
\text { Education and } \\
\text { training } \\
\end{array}$ & $\begin{array}{c}\text { R\&D } \\
\text { Transfer }\end{array}$ & $\begin{array}{c}\text { Cultural } \\
\text { and } \\
\text { social } \\
\text { norms } \\
\end{array}$ \\
\hline Portugal & 16,17 & 48,85 & 28,07 & 5,62 & 4,69 & 4,95 & 5,60 & 5,27 & 5,23 \\
\hline Spain & 5,59 & 45,26 & 25,97 & 2,13 & 3,99 & 4,02 & 3,50 & 3,93 & 4,39 \\
\hline Greece & 8,29 & 46,78 & 14,19 & 3,94 & 3,03 & 2,93 & 2,65 & 3,81 & 3,56 \\
\hline Italy & 8,15 & 30,54 & 25,66 & 3,19 & 3,98 & 3,09 & 2,99 & 3,93 & 3,52 \\
\hline Belgium & 10,85 & 31,89 & 40,26 & 4,53 & 5,28 & 6,48 & 3,14 & 4,55 & 4,11 \\
\hline Germany & 7,18 & 36,19 & 38,27 & 2,84 & 4,30 & 4,25 & 2,68 & 4,01 & 4,23 \\
\hline Ireland & 14,57 & 45,02 & 39,35 & 6,50 & 5,42 & 4,94 & 3,58 & 4,64 & 5,41 \\
\hline Luxembourg & 13,48 & 43,96 & 48,18 & 7,10 & 4,07 & 5,27 & 3,50 & 5,38 & 4,12 \\
\hline Netherlands & 9,43 & 40,55 & 48,36 & 4,30 & 5,74 & 5,38 & 4,92 & 5,14 & 5,70 \\
\hline $\begin{array}{r}\text { Switzerland } \\
\text { United }\end{array}$ & 8,44 & 36,70 & 70,22 & 4,79 & 4,65 & 3,95 & 3,78 & 4,01 & 4,95 \\
\hline Kingdom & 8,16 & 43,57 & 41,55 & 4,03 & 5,36 & 4,58 & 3,99 & 4,18 & 5,34 \\
\hline Croatia & 17,21 & 47,52 & 22,30 & 5,11 & 3,30 & 2,84 & 1,89 & 2,85 & 2,63 \\
\hline Hungary & 14,75 & 38,67 & 25,34 & 5,31 & 3,97 & 2,71 & 2,34 & 3,59 & 3,20 \\
\hline Poland & 19,97 & 55,92 & 32,89 & 5,74 & 4,73 & 4,60 & 2,48 & 3,51 & 4,36 \\
\hline Romania & 29,01 & 46,33 & 33,31 & 6,11 & 3,37 & 3,58 & 3,91 & 3,71 & 4,11 \\
\hline Slovakia & 15,69 & 52,38 & 26,44 & 6,49 & 4,28 & 3,68 & 3,41 & 3,23 & 3,46 \\
\hline Slovenia & 9,11 & 48,61 & 20,54 & 3,22 & 4,21 & 4,04 & 2,80 & 3,78 & 3,40 \\
\hline Estonia & 16,68 & 44,02 & 51,43 & 8,74 & 4,86 & 3,83 & 4,18 & 4,51 & 5,73 \\
\hline Finland & 10,86 & 37,39 & 48,62 & 4,04 & 4,31 & 5,35 & 3,87 & 3,89 & 4,45 \\
\hline Latvia & 22,24 & 49,08 & 34,73 & 8,57 & 4,50 & 3,74 & 3,97 & 3,50 & 4,79 \\
\hline Norway & 4,78 & 30,76 & 68,93 & 2,32 & 4,17 & 3,67 & 4,08 & 4,23 & 4,73 \\
\hline Sweden & 7,04 & 44,00 & 41,79 & 4,62 & 5,29 & 5,72 & 4,90 & 6,22 & 5,79 \\
\hline
\end{tabular}

Source: Authors, based and adapted from GEM (2015)

Table 1 - Research Hypotheses

\begin{tabular}{cll}
\hline Hypotheses & \multicolumn{1}{c}{ Dependents Variables } & \multicolumn{1}{c}{ Independent Variables } \\
\hline H1 & Entrepreneurial Intentions (EI) & Perceived Capacity (PC) \\
H2 & Entrepreneurial Intentions (EI) & Perceived Opportunities (PO) \\
H3 & Nascent Entrepreneurship (NE) & Entrepreneurial Intentions (EI) \\
H4 & Entrepreneurial Intentions (EI) & Financing Entrepreneurs (FI) \\
H5 & Entrepreneurial Intentions (EI) & Governmental Support (GS) \\
H6 & Entrepreneurial Intentions (EI) & Basic Education and Training (BET) \\
H7 & Entrepreneurial Intentions (EI) & Research \& Development (R\&D) \\
H8 & Entrepreneurial Intentions (EI) & Culture and Social Norms (CSN) \\
H9 & Nascent Entrepreneurship (NE) & Governmental Support (GS) \\
H10 & Funding for the Entrepreneur (FE) & Governmental Support (GS) \\
H11 & Research \& Development (R\&D) & Basic Education and Training (BET) \\
\hline
\end{tabular}


Table 5.1. - Variables Entered/Removed*

\begin{tabular}{l|l|c|c}
\hline \hline Model & \multicolumn{1}{|c|}{ Variables Entered } & $\begin{array}{l}\text { Variables } \\
\text { Removed }\end{array}$ & \multicolumn{1}{c}{ Method } \\
\hline 1 & $\begin{array}{l}\text { Nascent Entrepreneurship } \\
\text { Rate } \\
\text { R\&D }\end{array}$ & & $\begin{array}{l}\text { Stepwise (Criteria: Probability-of-F-to-enter } \\
<=, 050, \text { Probability-of-F-to-remove }>=, 100) \\
\text { Stepwise (Criteria: Probability-of-F-to-enter } \\
<=, 050, \text { Probability-of-F-to-remove }>=, 100)\end{array}$ \\
\hline
\end{tabular}

Table 5.2. - Model Summary*c

\begin{tabular}{|c|c|c|c|c|c|c|c|c|c|c|}
\hline \multirow[b]{2}{*}{ Model } & \multirow[b]{2}{*}{$\mathrm{R}$} & \multirow[b]{2}{*}{ R Square } & \multirow[b]{2}{*}{$\begin{array}{l}\text { Adjusted R } \\
\text { Square }\end{array}$} & \multirow[b]{2}{*}{$\begin{array}{l}\text { Std. Error of } \\
\text { the Estimate }\end{array}$} & \multicolumn{5}{|c|}{ Change Statistics } & \multirow[b]{2}{*}{$\begin{array}{l}\text { Durbin- } \\
\text { Watson }\end{array}$} \\
\hline & & & & & $\begin{array}{c}\text { R Square } \\
\text { Change }\end{array}$ & F Change & df1 & $d f 2$ & Sig. F Change & \\
\hline 1 & $.745^{\circ}$ & .555 & .533 & 4,11163 & .555 & 24,973 & 1 & 20 & .000 & \\
\hline 2 & $815^{b}$ & 664 &, 628 & 3,66798 & ,108 & 6,131 & 1 & 19 &, 023 & 1,741 \\
\hline
\end{tabular}

Table 5.3. - ANOVA* 
Table 6 - Kolmogorov-Smirnov residue test

\begin{tabular}{lcc}
\hline & \multicolumn{2}{c}{ Kolmogorov-Smirnov } \\
\cline { 2 - 3 } & Statistic & $p$ \\
Standardized residues &, 258 &, 001 \\
\hline
\end{tabular}

Table 7 - Hypotheses Results

\begin{tabular}{|c|c|}
\hline $\begin{array}{l}\text { H1: High levels of perceived capacity by the individual positively influence entrepreneurial } \\
\text { intention. } \\
\text { H2: High levels of perceived opportunities by the individual positively influence entrepreneurial } \\
\text { intention. } \\
\text { H3: The entrepreneurial intention positively influences the rate of Nascent Entrepreneurship. } \\
\text { H4: Finance for entrepreneurs positively influence entrepreneurial intention. } \\
\text { H5: Governmental support and policies positively influence entrepreneurial intention } \\
\text { H6: Basic education and training in entrepreneurship positively influence entrepreneurial intention. } \\
\text { H7: The level of research and development positively influence entrepreneurial intention. } \\
\text { H8: Culture and social norms held by the individual positively influence entrepreneurial intention. } \\
\text { H9: Governmental support and policies positively influence the rate of nascent entrepreneurship } \\
\text { H10: Governmental factors and policies positively influence high levels of finance for the } \\
\text { entrepreneur. } \\
\text { H11: Basic education and training in entrepreneurship positively influence the level of R\&D } \\
\text { development. }\end{array}$ & $\begin{array}{c}\text { Not Rejected } \\
\text { Rejected } \\
\text { Rejected } \\
\text { Rejected } \\
\text { Rejected } \\
\text { Rejected } \\
\text { Rejected } \\
\text { Not Rejected } \\
\text { Not Rejected }\end{array}$ \\
\hline
\end{tabular}

Table 5.4. - Coefficients*

\begin{tabular}{|c|c|c|c|c|c|c|c|c|}
\hline \multirow[b]{2}{*}{ Mod } & & \multicolumn{2}{|c|}{$\begin{array}{l}\text { Unstandardized } \\
\text { Coefficients }\end{array}$} & \multirow{2}{*}{$\begin{array}{c}\begin{array}{c}\text { Standardized } \\
\text { Coefficients }\end{array} \\
\text { Beta }\end{array}$} & \multirow[b]{2}{*}{$\mathrm{t}$} & \multirow[b]{2}{*}{ Sig. } & \multicolumn{2}{|c|}{ Collinearity Statistics } \\
\hline & & B & Std. Error & & & & Tolerance & VIF \\
\hline \multirow[t]{2}{*}{7} & (Constant) & ,273 & 2,622 & & ,104 & ,918 & & \\
\hline & Nascent Entrepreneurship Rate & 2,487 & .498 &, 745 & 4,997 &, 000 & 1,000 & 1,000 \\
\hline \multirow[t]{3}{*}{2} & (Constant) & 10,638 & 4,795 & & 2,218 & .039 & & \\
\hline & Nascent Entrepreneurship Rate & 2,529 & .444 & .758 & 5,692 & .000 & ,999 & 1,001 \\
\hline & R\&D Transfer & $-2,532$ & 1,023 &,- 330 & $-2,476$ &, 023 & ,999 & 1,001 \\
\hline
\end{tabular}

(a)

\begin{tabular}{ll|r|r|r|r|r}
\hline \hline Model & \multicolumn{1}{c|}{$\begin{array}{c}\text { Sumol } \\
\text { Squares }\end{array}$} & df & Mean Square & \multicolumn{1}{c|}{$\mathrm{F}$} & \multicolumn{1}{c}{ Sig. } \\
\hline 1 & Regression & 422,185 & 1 & 422,185 & 24,973 & $.000^{\circ}$ \\
& Residual & 338,109 & 20 & 16,905 & & \\
& Total & 760,294 & 21 & & & \\
\hline 2 & Regression & 504,666 & 2 & 252,333 & 18,755 &, $000^{\circ}$ \\
& Residual & 255,628 & 19 & 13,454 & & \\
& Total & 760,294 & 21 & & & \\
& & & & & \\
\end{tabular}

b. Predictors: (Constant), Nascent Entrepreneurship Rate

c. Predictors: (Constant), Nascent Entrepreneurship Rate, R\&D Transfer

a. Dependent Variable: Entrepreneurial Intention 
Page 21 of 21

International Journal of Innovation Science

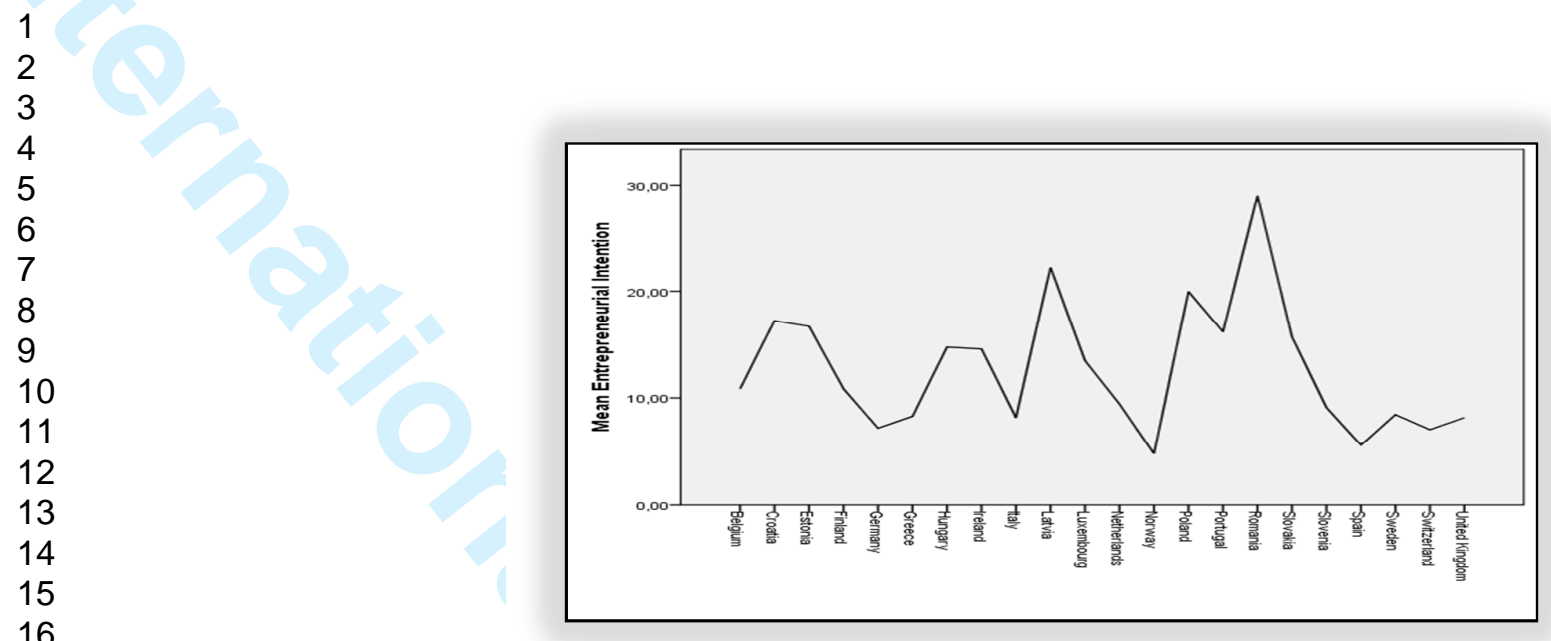

Figure 1: Mean Distribution “Entrepreneurial Intention” by countries 